\title{
Penguatan Organisasi dan Kelembagaan Ekonomi dalam Rangka Pemberdayaan Ekonomi Ummat di Kota Palembang Provinsi Sumatera Selatan
}

\author{
Imam Asngari ${ }^{1, *}$, Suhel $^{1}$, Muhammad Subardin ${ }^{1}$, Harunurrasyid ${ }^{1}$, Andi Nurul Astria Arief ${ }^{1}$, Mega \\ Debiyanti $^{1}$, Ria Aprianti $^{1}$ dan Putri Siski Ainul ${ }^{1}$ \\ ${ }^{1}$ Fakultas Ekonomi, Universitas Sriwijaya, Sumatera Selatan, Indonesia \\ * Email korespondensi: imam.asngari@unsri.ac.id
}

Info Artikel: Diterima: 25 Februari 2021; Disetujui: 03 November 2021; Dipublikasi: 05 November 2021

\begin{abstract}
Abstrak: Masyarakat Muslim di Indonesia, khususnya masyarakat di Kota Palembang, telah menyadari adanya kesadaran untuk beralih dari aktivitas ekonomi kapitalis tradisional ke aktivitas ekonomi Islam. Sudah ada Lembaga Keuangan Mikro dan Keuangan Islam (LEKIS), seperti Baitul Mall wa Tamwil (BMT), Koperasi Warmart Veteran Utama dengan 212 Mart, Lembaga Penelitian Ekonomi Mahasiswa Islam (LEMI) dan HMI Alumni Real Charity (ANA HMI). Tujuan dari kegiatan pengabdian ini adalah untuk penguatan kapasitas dan kelembagaan ekonomi islam yaitu dalam rangka pemberdayaan ekonomi ummat di Kota Palembang. Setelah pelatihan ini, rata-rata indeks pengetahuan terkait penguatan kapasitas dan kelembagaan ekonomi Islam peserta meningkat pesat. Terbukti secara statistik nilai Asymp.Sig $=0.00$ lebih besar dari $\alpha=0.05$.
\end{abstract}

Keywords: penguatan kapasitas; kelembagaan islam; kesejahteraan ekonomi ummat.

\section{Kutipan:}

Asngari, I., Suhel, Subardin, M., Harunurrasyid, Arief, A.N.A., Debiyanti, M., Aprianti, R., \& Ainul, P.S.(2021). Penguatan Organisasi dan Kelembagaan Ekonomi dalam Rangka Pemberdayaan Ekonomi Ummat di Kota Palembang Provinsi Sumatera Selatan. Sricommerce: Journal of Sriwijaya Community Services, 2(2): 113-124. DOI: https://doi.org/10.29259/jscs.v2i2.63

\section{PENDAHULUAN}

Sistem ekonomi kapitalistik telah menciptakan ketimpangan ekonomi, disertai dengan kemiskinan dan pengangguran karena faktor ketidakadilan dalam sistem yang lebih menguntungkan pemilik modal, sementara sistem tersebut tidak memiliki daya redistribusi sehingga kesejahteraan bersama tidak berwujud (Mannan, 1995; Husni, 2020). Kesadaran ummat islam di Indonesia pada umumnya telah muncul untuk hijrah kembali menerapkan kegiatan ekonomi berdasarkan muamalah islam. Sistem ekonomi Islam mengajarkan anti riba, keadilan, dan mekanisme Zakat untuk pemerataan kesenjangan pendapatan antara kaya dan miskin, sehingga ekonomi islam menjamin kesejahteraan bersama. Gerakan ekonomi syariah dalam tatanan makro ekonomi telah lahir lembaga keuangan bank islam sejak tahun 1992 dengan berdirinya Bank Muamalat Indonesia (BMI), yang kemudian menjadi tonggak kebangkitan ekonomi islam sejak awal tahun 1990-an hingga tahun 2020 telah terdapat sebanyak 14 bank syariah. Sementara itu, dalam tatanan kelembagaan mikro ekonomi syariah, beberapa diantaranya Baitul Mall wa tamwil (BMT) yang muncul di tahun 1980-an (https://id.wikipedia.org/wiki/BMT) dan di tahun 2017 mulai berdirinya Koperasi Syariah 212 yang berpusat di Bogor (http://koperasisyariah212.co.id/). Hadirnya BMT dan Koperasi Syariah, mendorong kebangkitan kembali dan kelahiran lembagalembaga ekonomi islam, seperti di kalangan mahasiswa islam di Palembang telah lahir Lembaga 
Ekonomi Mahasiswa Islam (LEMI) tahun 2019 dan lembaga Amal Nyata Alumni HMI (ANA-HMI) pada tahun 2020.

Pemberdayaan ekonomi masyarakat telah menjadi program pemerintah. Namun semua itu belum cukup, karena sebagian besar umat masih terjebak oleh sistem ekonomi kapitalis, yang memanfaatkan nilai tambah ekonomi dari kegiatan yang mencakup unsur-unsur seperti rabbawi, tadlis, dan perjudian (maysir). Lembaga-lembaga ekonomi dan keuangan Islam merupakan pilihan untuk menerapkan sistem ekonomi Islam dan sarana (halallul-tayyibah) bagi umat untuk hijrah dari sistem ekonomi yang ribawi ke sistem ekonomi yang non ribawi yang halal lagi baik. Mengelola lembaga ekonomi dan keuangan mikro syariah (LKMS) relatif tidak jauh berbeda dengan mengelola lembaga keuangan bank pada umumnya. Perbedaan yang mendasar terletak pada jumlah pembiayaan yang disalurkan serta ketetatan persyaratan yang diberikan pada nasabah. Pengelola lembaga ekonomi dan keuangan mikro biasanya juga dilakukan oleh lembaga relatif kecil seperti BPR dan koperasi. Perbedaan lainnya adalah dalam upaya pemberdayaan masyarakat berupa penyiapan kelompok sasaran, pelatihan dan pendampingan. Unsur pemberdayaan ini tidak dimiliki oleh lembaga ekonomi dan keuangan yang lain.

Kota Palembang memiliki usaha skala UMKM, dimana usaha skala mikro umumnya masih bersifat informal, yaitu belum memiliki perizinan, dan lokasi usahanya belum menetap. Sedangkan usaha skala kecil dan menengah umumnya telah memiliki perizinan dan bersifat formal, berada di lokasi tertentu dan menetap. Keberadaan usaha-usaha skala mikro, kecil dan menengah masih membutuhkan perhatian dan edukasi tentang prinsip binis dalam islam, manajemen dan tata kelola bisnis serta introduksi teknologi dalam pengembangan bisnis menuju pola usaha modern, amanah dan akuntabel (Soediro et.al., 2021).

Untuk memajukan dan memperkuat ekonomi Ummat tidak cukup hanya mengandalkan kekuatan satu elemen saja, cendekiawan, pengusaha, penguasa, perguruan tinggi dan berbagai elemen lainnya juga harus dilibatkan. Tujuan dari lembaga ekonomi dan keuangan Islam adalah untuk mengembangkan dan memakmurkan umat. Jika Bank Syariah, BMT, 212 Koperasi Syariah dan lembaga ekonomi Ummat (LEKIS) lainnya dapat menjalankan usaha secara profesional dan bertanggung jawab, maka akan mampu memperkuat perekonomian. Sebagaimana misi Koperasi Syariah 212 yaitu untuk menjalankan usaha secara partisipatif (serikat pekerja), profesional (berwenang), dan mencapai uma (izzah) yang luhur.

Permasalahan kelompok ekonomi telah menyebabkan terjadinya eksploitasi konsumen dan produsen skala kecil. Masyarakat Muslim biasanya menjadi konsumen daripada pelaku pasar, memiliki daya tawar rendah, dan kehilangan nilai tambah karena mekanisme pasar yang tidak sempurna. Di sisi lain, jiwa kewirausahaan muslim masih rendah, karena tidak ada proses yang menghubungkan input, proses dan output dari satu produk ke produk lainnya. Kontrol dan regulasi pasar oleh kelompok perusahaan hampir sempurna, yang mengarah pada distorsi dan ketimpangan ekonomi yang sangat tinggi. Masalah lainnya adalah mengekstraksi surplus ekonomi ummat, karena ummat sebagian besar merupakan konsumen atau produsen skala kecil. Hilangnya surplus konsumen dan produsen kecil terjadi dalam sistem pertukaran dengan mekanisme pasar dengan kekuatan monopoli dan daya konsumsi yang tidak seimbang. Secara umum, masalah utama yang sering muncul di kalangan pengusaha skala mikro, kecil dan menengah (UMKM) di perkotaan dan pedesaan adalah keterbatasan dana akibat individualisme dan kurang berjamaah dalam bermuamalah, aksesibilitas kelembagaan dan keterbelakangan teknologi. Inilah kelemahan UMKM, petani, dan konsumen menghadapi sistem kapitalis yang telah membentuk kelompokkelompok yang dapat dieksploitasi melalui struktur pasar monopoli, oligopoli, oligopoli atau monopoli. Masalah keterbatasan modal, teknologi dan rantai nilai akibat sempitnya jaringan usaha berdampak pada nilai tambah, efisiensi dan penurunan keuntungan usaha umat Islam, sehingga kesejahteraan juga sangat rendah. Oleh karena itu, diperlukan upaya edukasi kepada masyarakat untuk memajukan dan mengembangkan upaya ekonomi secara berjamaah (partisipasi dalam sinergi), penghimpunan modal melalui kekuatan bersama LEKIS, dan transfer budaya dan teknologi bisnis (Hamidi et.al., 2020).

Sebagai wujud tanggung jawab penguatan dan kemajuan ekonomi ummat, seluruh perguruan tinggi perlu memberikan pendidikan ekonomi Islam kepada anggota dan pengelola LEKIS 
khususnya di Kota Palembang untuk memperkuat kapasitas dan kelembagaan LEKIS dalam rangka pemberdayaan ekonomi ummat di Kota Palembang. Hasil yang diharapkan dari pengabdian ini adalah terwujudnya penguatan kelembagaan ekonoi islam sehingga ada peningkatan partisipasi anggota dalam lembaga ekonomi (LEKIS), peningkatan belanja di BMT dan 212 Mart, pengelolaan lembaga secara profesionel, kemampuan anggota dan pengurus lembaga ekonomi islam mampu menerapkan teknologi untuk menjalankan administrasi dan operasi dalam bisnis.

\section{STUDI PUSTAKA}

Penguatan kapasitas dapat didefinisikan sebagai proses pengembangan kemampuan individu, kelompok atau organisasi (Yusuf \& Tawai, 2019). Selain itu, hal ini juga dapat diartikan sebagai upaya memperkuat kapasitas melalui pengembangan kemampuan serta penguasaan kemampuan, sehingga individu atau kelompok dapat bertahan dan menghadapi setiap perubahan dan tantangan yang terjadi. Milen (2004) menunjukkan bahwa peningkatan kapasitas adalah proses peningkatan berkelanjutan dari individu atau kelompok. Penguatan kapasitas masyarakat merupakan hal yang sangat penting, sebagai upaya agar masyarakat dapat mencapai kesejahteraan. Pemberdayaan juga berarti mendorong masyarakat untuk lebih menggali potensi yang dimilikinya sehingga dapat meningkatkan kualitas dirinya untuk terus berkembang. Pemberdayaan masyarakat bertujuan agar masyarakat dapat lebih mandiri dalam mencapai tujuannya.

Tercapainya kesejahteraan manusia merupakan titik berat yang sangat diharapkan dari penguatan ekonomi masyarakat. Aspek ekonomi ini sangat penting dan termasuk salah satu dari lima aspek yang dilindungi dalam usul al figh yang terkenal dengan al-umur al-daruriyah li al-nas, yaitu agama, jiwa, akal, keturunan, dan harta (al-Zuhaili dalam Anwar, 2011). Dalam usaha penguatan ekonomi umat ini, tentunya yang pertama kali dilihat adalah bagaimana penguatan ekonomi dalam lingkup yang lebih kecil, yaitu keluarga. Hal ini sesuai dengan Firman Allah dalam al-Qur an surat an-Nisa' ayat 9: "Dan hendaklah takut pada Allah orang-orang yang sekiranya meninggalkan anak-anak yang lemah di belakang mereka yang mereka khawatir terhadap (kesejahteraan) mereka, maka hendaklah mereka bertaqwa kepada Allah dan hendaklah mereka mengucapkan perkataan yang benar"

Penguatan ekonomi umat dapat dilakukan dengan pengembangan kewirausahaan yang dilakukan oleh individu atau kelompok, sehingga tercipta kemandirian usaha ekonomi produktif. Pada akhirnya akan terwujud individu maupun kelompok yang semakin sejahtera dan mandiri. Salah satu indikasi kesejahteraan masyarakat yaitu adanya kemampuan fungsional individu atau kelompok dalam memenuhi kebutuhan dasar sehingga mampu memberikan kontribusi terhadap kebutuhan kehidupan masyarakat. Lembaga ekonomi dan keungan mikro islam (LEKIS) yang memiliki kekuatan moral dan mendapatkan legalisasi dari umat, mempunyai peranan penting dalam penguatan ekonomi. Secara umum, LEKIS paling tidak memiliki dua peranan penting yang perlu diimplementasikan, yaitu peranan terkait mauidhah hasanah dan uswatun hasanah (Anwar, 2011). Peran LEKIS terkait mauidhah hasanah dapat diimplementasikan dengan peningkatan kualitas sumber daya manusia dan dapat diwujudkan dengan memberikan pemahaman tentang ekonomi syari'ah. Sedangkan peran LEKIS terkait uswatun hasanah dapat diimplementasikan dengan cara pengelolaan zakat, infaq, dan shadaqah. Pengelolaan ZIS ini bertujuan untuk meningkatkan kesejahteraan mustahiq. Didalam al-Qur'an surat Al-Hasyr ayat 7 juga tertulis bahwa zakat, infaq, dan shadaqah juga bertujuan untuk mengurangi kesenjangan yang terjadi. Lembaga ekonomi dan keungan mikro islam dapat menjadi faktor kritikal yang efektif dalam penanggulangan kemiskinan. Peningkatan akses dan pengadaan sarana penyimpanan, pembiayaan, dan asuransi yang efisien dapat berpeluang untuk mengeluarkan masyarakat yang terjerat kemiskinan.

Untuk melakukan penguatan kapasitas usaha mikro kecil menengah (UMKM) dan koperasi, lembaga penyedia jasa pengembangan bisnis akan terus dikembangkan untuk memberikan layanan informasi, konsultasi, pelatihan, bimbingan, bantuan bisnis, fasilitasi dalam perluasan pasar, akses permodalan, pengembangan teknik produksi melalui teknologi tepat guna, serta 
pengembangan organisasi dan manajemen (Bappenas, 2009).

Dalam pemberdayaan koperasi, permasalahan yang sering ditemui salah satunya belum meluasnya pemahaman masyarakat terkait koperasi sebagai badan usaha dengan struktur kelembagaan dan insentif yang unik apabila dibandingkan dengan badan usaha lainnya. Sama halnya dengan koperasi, dalam pemberdayaan UMKM juga masih menemui permasalahan seperti iklim usaha yang masih kurang kondusif yang menghambat pertumbuhan UMKM, peningkatan produktivitas UMKM masih sangat kecil apabila dibandingkan dengan produktivitas usaha lain, serta sulitnya meningkatkan nilai tambah usaha yang diakibatkan keterbatasan penguasaan teknologi dan modal pada UMKM.

Untuk dapat meningkatkan daya saing usaha mikro kecil menengah dalam menghadapi mekanisme pasar yang semakin terbuka dan kompetitif, informasi tentang pasar faktor produksi dan pasar produksi sangat diperlukan oleh pelaku UMKM. Begitu pula dengan Koperasi, baik masyarakat umum maupun anggota koperasi tersebut memerlukan pemahaman yang mumpuni terkait tujuan dan fungsi koperasi. Tercapainya revitalisasi koperasi akan terwujud jika masyarakat maupun anggota koperasi juga diberdayakan.

\section{METODE}

Metode yang akan digunakan untuk mencapai tujuan kegiatan yang ditetapkan adalah sebagai berikut:

1. Penyuluhan; dilakukan dengan presentasi dan diskusi mengenai konsep dan nilai-nilai ekonomi syari'ah, kerjasama syariah, dan tata kelola lembaga.

2. Pendampingan; dilakukan dengan cara memotivasi semangat dan perilaku positif khalayak sasaran seperti kemandirian, mengambil keputusan, kreatif dan inovatif. Secara khusus pendampingan dilakukan dengan pendekatan kelompok sehingga ada proses interaksi dan komunilkasi yang baik. Target untuk pencapaian tujuan kegiatan adalah meningkatkan militansi ekonomi syariah di kalangan anggota dan pengurus, sehingga pendapatan LEKIS meningkat, dan pada akirnya nanti tingkat kesejahteraan anggota ikut meningkat.

3. Percontohan; dilakukan dengan pembentukan model percontohan ANA HMI yang dimaksudkan untuk memberikan pengetahuan dan keterampilan kepada anggota dan pengurus. Target untuk pencapaian tujuan kegiatan adalah terbentuknya pengurus sesuai $A D / A R T$, program kerja dan tersusunnya akad syari'ah.

Sasaran peserta yang dipilih merupakan pengurus dan anggota Koperasi Warmat Veteran Utama (KWVU), karyawan 212 mart dan pengurus Lembaga Ekonomi Mahasiswa Islam (LEMI) di Kota Palembang. Penetapan sasaran ini merupakan suatu upaya untuk pemberdayaan ekonomi ummat yang berdampak pada penguatan kapasitas dan kelembagaan ekonomi islam di Kota Palembang. Selain itu, diharapkan para pengurus dapat memberikan pembinaan dalam penguatan kapasitas dan kelembagaan ekonomi islam kepada pengurus dan anggota KWVU, 212 mart, maupun LEMI.

Evaluasi akan dilakukan dengan membagikan kuesioner tentang materi penguatan kapasitas dan kelembagaan ekonomi islam. Pre test dan post test digunakan sebagai instrumen evaluasi yang dibagikan sebelum dan setelah kegiatan dilaksanakan untuk mengetahui pemahaman peserta terhadap materi yang disampaikan. Penilaian keberhasilan kegiatan juga berdasarkan skor tes peserta dan perubahan skor tes peserta. Selain itu, penilaian berdasarkan dari aspek materi pelatihan, metode pelatihan, pelaksanaan kegiatan dan aspek kepuasan peserta terhadap narasumber, dan panitia. Metode pengukuran dilaksanakan dengan skala Likert yang diberikan dalam kuisioner.

\section{HASIL DAN PEMBAHASAN}

Kegiatan pengabdian pelatihan Penguatan Kapasitas Dan Kelembagaan Ekonomi Islam Dalam Rangka Pemberdayaan Ekonomi Ummat dilaksanakan selama dua hari. Pengabdian hari pertama diadakan di KWVU, dan hari kedua diadakan di fakultas ekonomi Universitas Sriwijaya. Peserta yang mengikuti kegiatan pengabdian Penguatan Kapasitas Dan Kelembagaan Ekonomi Islam Dalam 
Rangka Pemberdayaan Ekonomi terdiri dari 22 orang pengurus dan anggota Koperasi Warmat Veteran Utama (KWVU), serta karyawan 212 mart dan 11 orang pengurus Lembaga Ekonomi Mahasiswa Islam (LEMI).

\subsection{Pemecahan Masalah}

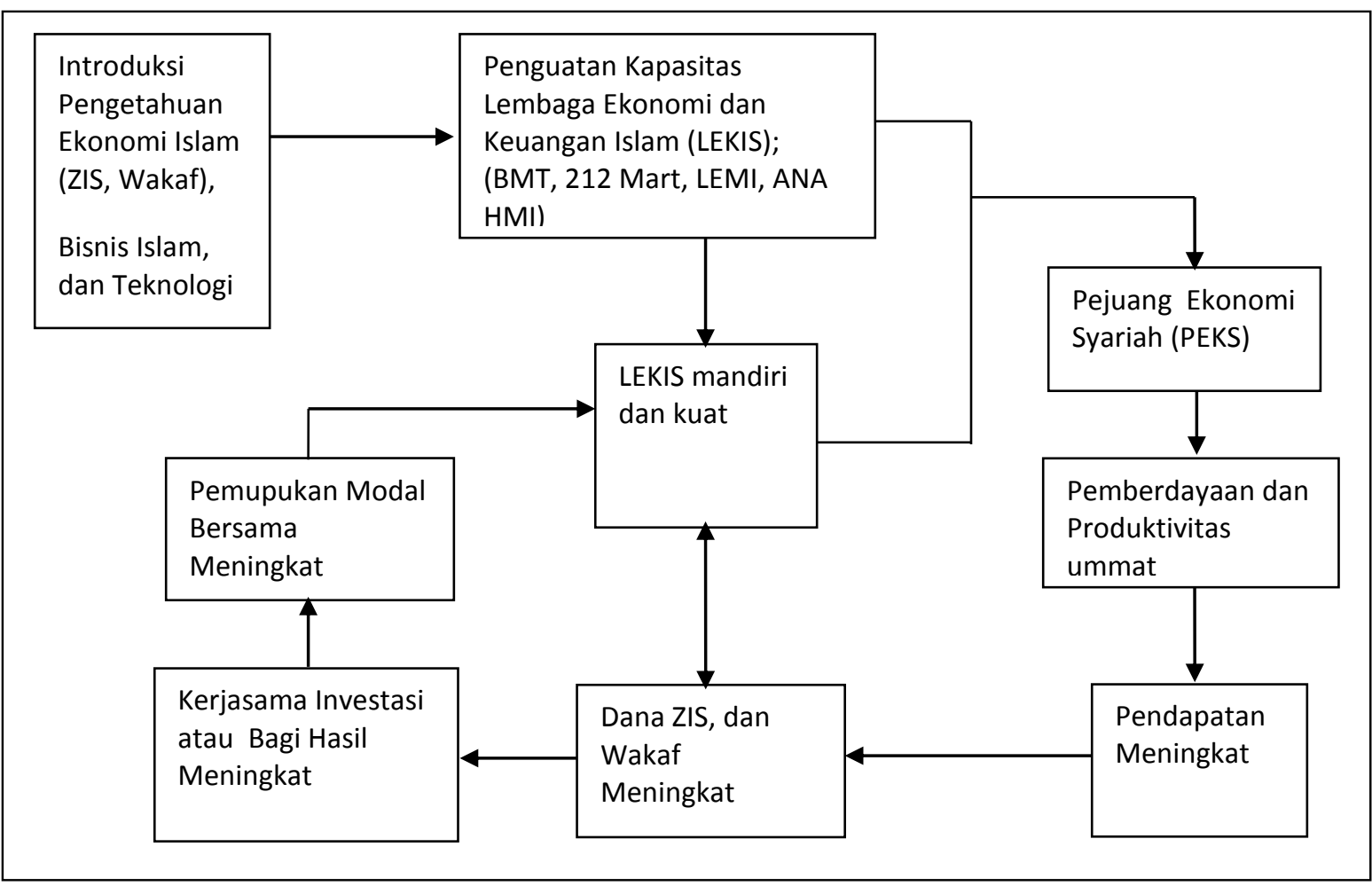

Gambar 1. Introduksi Iptek untuk memutus lingkaran setan kemiskinan ummat islam

Solusi permasalahan lemahnya ekonomi ummat diatasi dengan introduksi pengetauan ekonomi islam, muamalah syariah, kerjasama bisnis berbasis bagi hasil, dan teknologi dalam pengembangan bisnis islam yang professional dan amanah. Melalui kelompok sasaran para anggota dan pengurus lembaga ekonomi dan keungan mikro islam (LEKIS) yang ada, akan ditingkatkan kapasitasnya, dan kemampuan organisasinya, sehingga mampu menjadi pejuang ekonomi syariah. Para pejuang ekonomi syariah, akan mampu meperdayakan ekonomi ummat, meningkatkan kesejahteraan dan melahirkan generasi yang mulia karena sejahtera. Pada akhirnya, dana ZISWAF akan meningkat, dan pemupukan modal lembaga ekonomi dan keungan mikro islam (LEKIS) terus meningkat, akan memperbesar kapasitas LEKIS untuk mencipatakan nolai tambah dan meningkatkan kesejahteraan ummat islam.

Sementara Ibu Divia menerima dengan baik dan berterima kasih telah dikunjungi oleh Tim dosen Unsri, semoga ilmu yang akan diberikan kepada kami bisa kami pahami yang kemudian bisa berguna bagi kemajuan koperasi dan 212 mart di bawah KWVU di Palembang ini. Setelah itu, Peserta dibagikan lembaran pretest sebelum diberikan paparan materi untuk mengetahui pengetahuan dasar peserta tentang penguatan kapasitas dan kelembagaan ekonomi islam.

\subsection{Pelaksanaan Hari 1: KWVU 212 Mart}

Sambutan pertama dilakukan oleh Ketua Tim Pelaksana yaitu Dr. Imam Asngari, SE, M.Si dan Sambutan oleh Ibu Divia perwakilan pengurus Koperasi Warmat Veteran Utama (KWVU). Ketua pelaksna menyampaikan maksud dan tujuan pengabdian di KWVU adalah dalam ranga memberikan penguatan dan motivasi kepada anggota dan pengurus koperasi maupun pegawai 212 Mart di bawah KWVU. Tujuannya agar kita semua memahami peta masalah ekonomi ummat, agar kesadaran kerjasama meningkat, sehingga tercipta kolaborasi KWVU, anggota, dan usaha 
bisnis ummat yang lain seperti UKM, dan lainnya.

\subsubsection{Materi Potensi, Masalah, dan Keunggulan Koperasi 212}

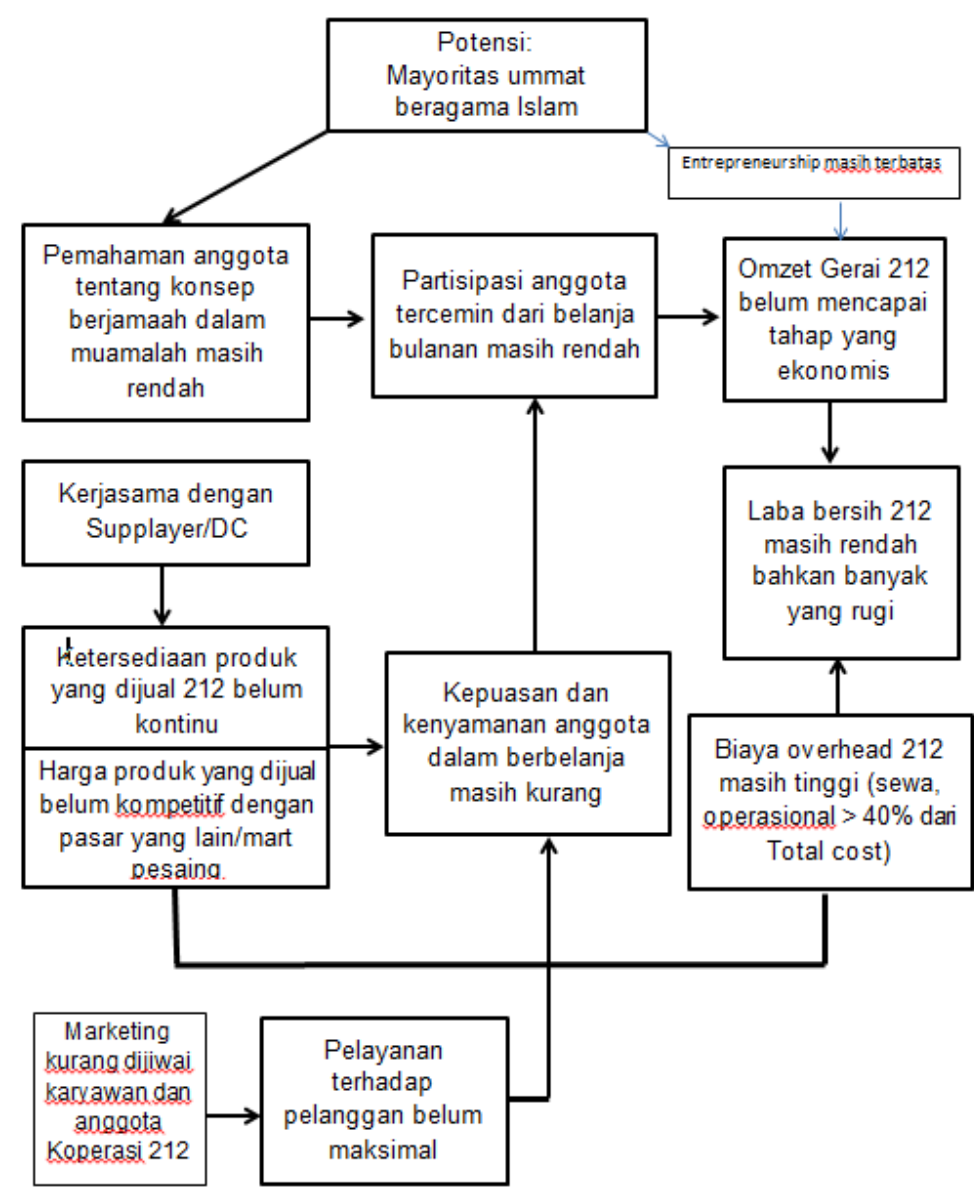

Gambar 2. Potensi dan Masalah Koperasi 212

Sumber Keunggulan Koperasi:

1. Trust Capital dapat diartikan pengumpulan modal. Hal ini dapat dilakukan pada koperasi karena usaha yang awalnya dilakukan sendiri-sendiri dapat dikelola bersama-sama dengan anggota lain. Semakin banyak anggota maka akan semakin besar modal yang dapat dikumpulkan dan kedudukan modal usaha koperasi semakin kuat sehingga meningkatkan kemampuan koperasi dalam bersaing dengan pesaingnya.

2. Economies of scale merupakan penghematan pada koperasi yang timbul akibat penambahan kapasitas produksi. Penghematan tersebut sangat memungkinkan karena apabila adanya penambahan anggota berarti kapasitas produksi dikoperasi juga akan bertambah, kebutuhan bahan baku bertambah, dan koperasi dapat membeli bahan dalam jumlah besar. Economies of scale dapat terwujud pada tingkat produksi optimal yaitu pada saat biaya rata-rata jangka panjang terendah.

3. Participation. Keunggulan koperasi dapat diperoleh melalui partisipasi baik partisipasi kontributif dalam penyerahan keuangan dan pengembalian keputusan, maupun partisipasi intensif dalam pemanfaatan pelayanan koperasi.

4. Reduced Uncertainty. Pengendalian ketidakpastian sangat memungkinkan mengingat adanya pasar internal pada koperasi. Apabila terjadi kerugian akibat resiko kegiatan operasional, maka resiko tersebut akan ditanggung bersama-sama, sehingga biaya resiko peranggota menjadi lebih rendah.

5. Competition. Apabila sekelompok orang membentuk koperasi, maka koperasi tersebut dapat bersaing kuat di pasar. Apabila beberapa koperasi primer membentuk koperasi sekunder, maka koperasi yang terbentuk akan memiliki kedudukan yang kuat dipasar yang 
lebih luas. Efisiensi koperasi dapat meningkat melalui integritas vertikal.

6. Inter-linkage Market merupakan hubungan transaksi antarpelaku ekonomi dipasar. Transaksi antara koperasi penjualan dengan koperasi produsen, koperasi penjualan dengan koperasi simpan pinjam, dan koperasi produsen dengan koperasi simpan pinjam akan dapat mengurangi biaya transaksi karena dapat terhindar dari sistem rentenir. Koperasi dapat menciptakan kerjasama yang saling menguntungkan antara pelaku dalam interlinkage market tersebut.

7. Reduced Transaction Cost dapat dilakukan karena informasi pengembangan koperasi banyak tersebar diantara para anggotanya, tidak perlu melakukan kontrak antara anggota dan koperasi, terdapat kontrol sosial dalam koperasi tidak perlu manajemen mengeluarkan biaya monitoring dalam jumlah yang besar, terdapat pasar internal koperasi.

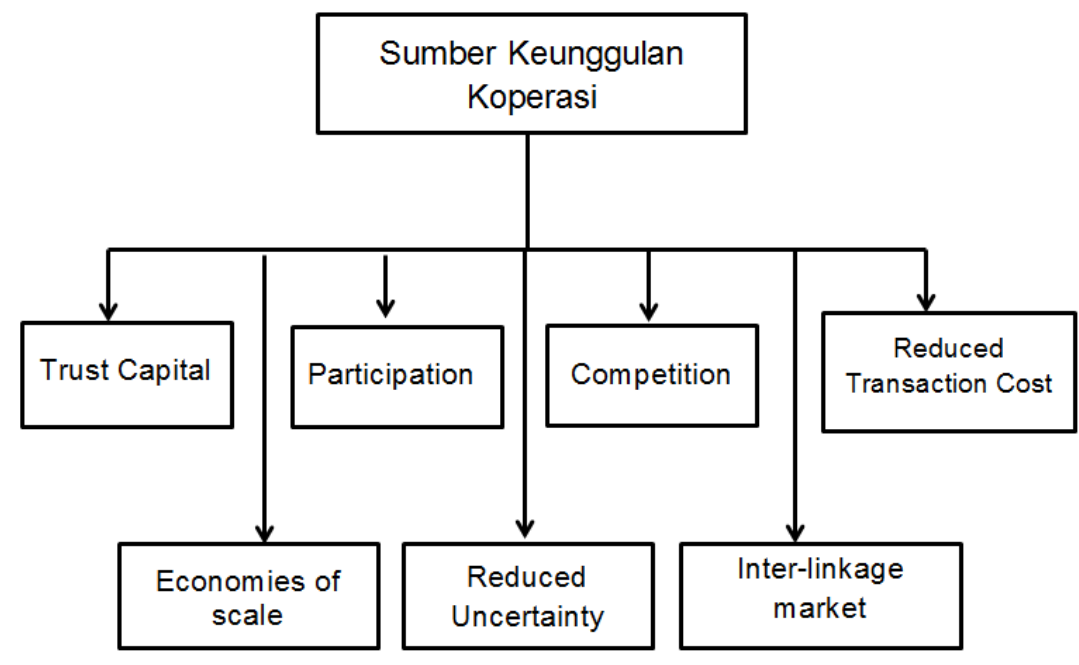

Gambar 3. Keunggulan Koperasi 212

\subsubsection{Kerjasama Syariah}

Menurut syariah, syirkah adalah akad (transaksi) antara dua orang atau lebih, yang bersepakat untuk melakukan kerja yang bersifat financial dengan bermaksud mendapatkan keuntungan. Akad syirkah mengharuskan adanya ijab dan qabul sekaligus (An-Nabhani, 2004). Syarat keabsahan akad syirkah harus memiliki objek akad, yaitu berupa pengelolaan. Sistem Kerjasama dalam ekonomi islam ada 5 (lima), yaitu syirkah inan atau musyarakah adalah kerjasama dua pihak (orang atau badan) dengan harta masing-masing; Syirkah Abdan atau Kerja sama usaha (kemitraan bisnis) antara dua orang atau lebih dengan badan (tenaga) masing-masing pihak, tanpa menyertakan harta mereka, yakni dalam bidang usaha yang mereka upayakan dengan tangan-tangan atau tenaga mereka, untuk melakukan kerja tertentu, baik kerja pemikiran maupun fisik; Syirkah Mudharabah disebut juga dengan qiradh, Kerjasama usaha (kemitraan bisnis) antara badan (tenaga) dengan harta; Syirkah Wujuh atau kerjasama usaha (kemitraan bisnis) antara dua bahan dengan modal dari pihak lain; dan Syirkah Mufawadah atau kerjasama dua mitra bisnis sebagai gabungan dari semua bentuk syirkah yang telah disebutkan di atas.

\subsubsection{Masalah Ekonomi Ummat}

Dan tolong-menolonglah kamu dalam (mengerjakan) kebajikan dan takwa, dan jangan tolong-menolong dalam berbuat dosa dan pelanggaran. Dan bertakwalah kamu kepada Allah, sesungguhnya Allah amat berat siksa-Nya. [Surat Al-Ma'idah: 2]

Problem besar yang masih dihadapi ummat adalah kekurangpahaman tentang hakekat berjamaah dalam ekonomi, karena minimnya pengetahuan ekonomi dan bisnis islam, sehingga tolong menolong dalam konteks taqwa belum menyentuh keseluruhan aspek khususnya dalam kolaborasi ekonomi. Dampaknya adalah ummat masih parsial dalam beribadah dan bermuamalah, padahal konteks nilai amalnya diperhitungkan sama penting baik ibadah ataupun muamalah. 
Rendahnya pemahaman bisnis syariah, menyebabkan kegiatan nvestasi ummat yang mayoritas relatif masih rendah. Meskipun usaha UMKM adalah mayoritas usaha yang dilakukan ummat, namun nilai tambahnya masih rendah, produktivitas dan daya saing juga masih rendah. Hal ini akibat kurangnya kolaborasi dan ta'awun dalam bisnis.

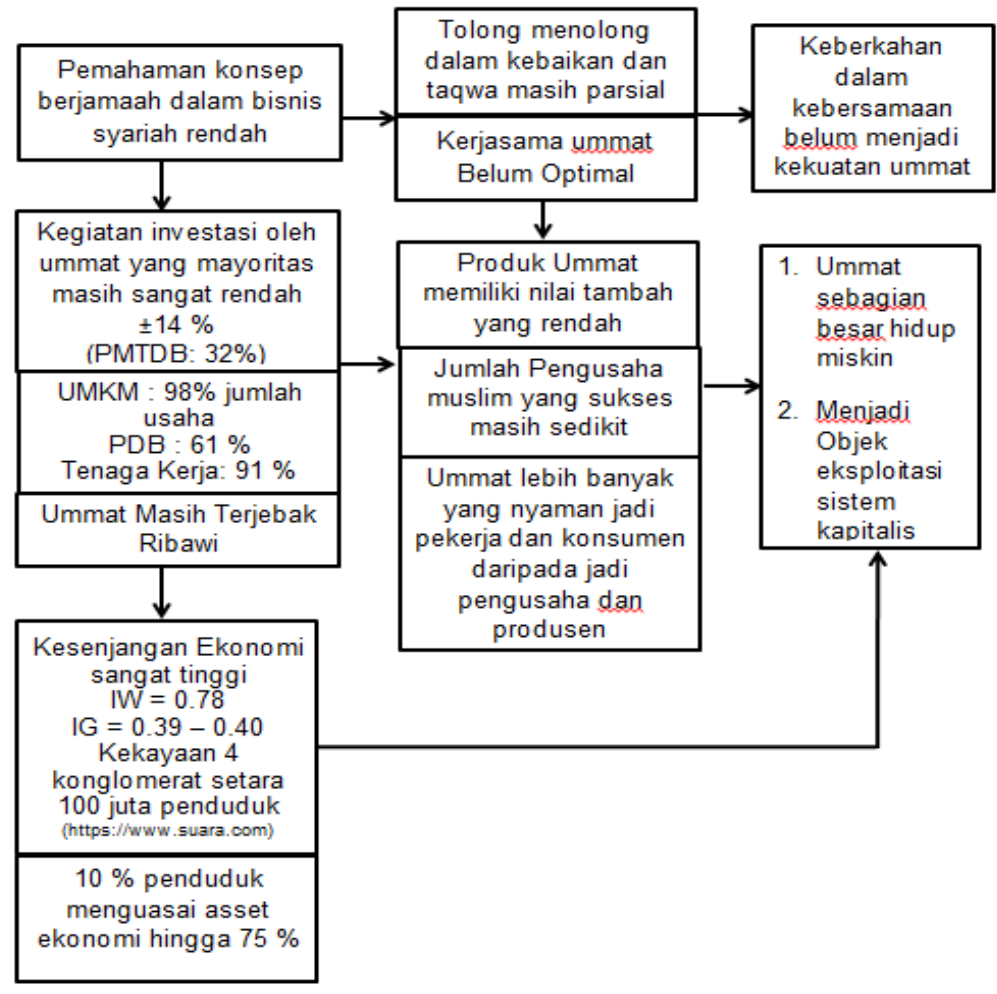

\section{Gambar 4. Permasalahan Ekonomi Ummat}

Rendahnya pemahaman bisnis syariah mengakibatkan pengusaha muslim yang sukses masih terbatas, dan mayoritas ummat lebih suka jadi pekerja dan konsumen ketimbang menjadi pengusaha dan produsen. Selain itu, ummat juga masih terjebak ribawi, sehingga yang kaya makin kaya dan yang miskin tetap miskin karena tereksploitasi oleh system kapitalisme. Akibatnya kesenjangan dan kemiskinan tinggi.

\subsection{Pelaksanaan Hari 2: Fakultas Ekonomi Palembang}

Kegiatan pengabdian ini dimulai dengan sambutan pertama yang dilakukan oleh Ketua Tim Pelaksana yaitu Dr. Imam Asngari, SE, M.Si dan Sambutan oleh Dimas perwakilan pengurus Lembaga Ekonomi Mahasiswa Islam (LEMI). Ketua pelaksana menyampaikan maksud dan tujuan pengabdian kepada LEMI adalah dalam rangka memberikan penguatan dan motivasi kepada pengurus LEMI. Tujuannya agar kita semua memahami peta masalah ekonomi ummat, agar kesadaran kerjasama ekonomi islam meningkat, sehingga tercipta kolaborasi LEMI dengan usaha bisnis ummat yang lain seperti UKM, 212 Mart dan lainnya. Kemudian, Peserta dari pengabdian hari kedua juga diberikan lembaran pretest sebelum diberikan paparan materi untuk mengetahui pengetahuan dasar peserta tentang penguatan kapasitas dan kelembagaan ekonomi islam.

\subsubsection{Penguatan Organisasi LEMI dalam Muamalah}

Kapasitas organisasi LEMI dapat ditingkatkan dengan cara menjalin kerjasama ummat dalam bisnis islam akan memberikan kekuatan ekonomi, akan lebih menjadi produktif, efisien dan dapat meningkatkan kesejahteraan. LEMI merupakan lembaga strategis bagi kader HMI dalam belajar berkiprah di kegiatan ekonomi dan bisnis. Program kerja yang dapat dilakukan adalah menghimpun kekuatan mahasiswa islam dama kegiatan bisnis yang bisa dijalankan sambal kuliah. Bidang bisnis pendidikan, pelatihan, jual beli online, dan juga program mualamah islam seperti menjadi bagian penggerak Amal Nyata Alumni HMI (ANA HMI). 


\subsubsection{Kewirausahaan dalam Praktek}

Wirausaha adalah orang yang pandai atau berbakat mengenali produk baru, menentukan cara produksi baru, menyusun operasi untuk mengadakan produk baru, mengatur permodalan operasinya, serta memasarkannya. Kewirausahaan juga dapat dikatakan sebagai proses dalam mengerjakan sesuatu yang baru (kreatif) dan berbeda (inovatif) yang memberikan manfaat dan nilai lebih (Rusdiana, 2018).

Wirausahawan biasanya memiliki jiwa mandiri. Hal ini didukung oleh cara berpikir kreatif. Pemikiran kreatif didukung oleh dua hal, yaitu pengerahan daya imajinasi dan proses berpikir ilmiah. Dengan pemikiran yang kreatif, maka berbagai macam permasalahan dapat diatasi dengan baik oleh wirausahawan. Seorang wirausahawan juga harus memiliki kemampuan inovasi. Kemampuan inovasi wirausahawan merupakan proses untuk mengubah peluang suatu gagasan dan ide-ide yang dapat dijual. Jika seorang wirausaha ingin sukses di dalam dunia usaha, mereka harus membuat menjadi wirausahawan harus memiliki niat dan keinginan yang kuat. Berdasarkan survei pengusaha yang berhasil pasti pernah mengalami berbagai macam kegagalan. Jika seorang wirausahaan tidak memiliki niat dan keinginan, apabila mengalami kegagalan, maka ia akan terlalu cepat menyerah dan putus asa. Seorang wirausaha harus dapat melihat peluang. Untuk dapat memperoleh peluang, wirausahawan harus memiliki kemampuan untuk menghasilkan sesuatu yang baru, menghasilkan nilai tambah, merintis usaha baru, ataupun melakukan teknik dan proses baru.

\subsection{Evaluasi Kegiatan}

Evaluasi dilakukan untuk memperoleh umpan balik dari peserta. Hasil evaluasi sebelum dan sesudah Pelatihan Penguatan Kapasitas dan Kelembagaan Ekonomi Islam sebagai berikut;

Tabel 1. Hasil Evaluasi Peserta Pelatihan Penguatan Kapasitas dan Kelembagaan Ekonomi Islam

\begin{tabular}{clcc|cccc}
\hline No & \multicolumn{1}{c}{ Nama } & $\begin{array}{c}\text { Pre- } \\
\text { Test }\end{array}$ & $\begin{array}{c}\text { Post- } \\
\text { Test }\end{array}$ & No & \multicolumn{1}{c}{ Nama } & $\begin{array}{c}\text { Pre- } \\
\text { Test }\end{array}$ & $\begin{array}{c}\text { Post- } \\
\text { Test }\end{array}$ \\
\hline 1 & Dimas Valentino & 80 & 90 & 17 Dr. Aryani Aziz & 80 & 90 \\
2 & M. Darul Yukofani & 70 & 90 & 18 Tierzayantie & 70 & 80 \\
3 & Muhammad Farhan & 75 & 90 & 19 Purnama Indah & 70 & 85 \\
4 & Ramadhan Saka Yudha & 50 & 60 & 20 Yossi Merisca & 80 & 90 \\
5 & Khalifah Islami & 90 & 90 & 21 & Bilhaq Al Aza Wijaya & 60 & 85 \\
6 & Trisna Wulandari & 45 & 85 & 22 Rizki Pratama & 65 & 65 \\
7 & Edzarlin & 50 & 75 & 23 Sinta Tri Wahyuni & 50 & 60 \\
8 & Abdul Hakim Aljann & 65 & 85 & 24 Rilly Sakinah Putri & 60 & 60 \\
9 & Muhammad Riza & 60 & 85 & 25 Hendriansyah & 60 & 65 \\
10 & M. Deni Tri Utomo & 35 & 50 & 26 Purnama Sari & 60 & 60 \\
11 & Fajar Sani Nasution & 70 & 90 & 27 Jesika Agustini & 20 & 50 \\
12 & Purnamawaty & 80 & 85 & 28 Rizky Purnama Sari & 65 & 80 \\
13 & Patrio Arrohman & 70 & 85 & 29 Mastura & 60 & 60 \\
14 & Devia Septiani & 70 & 85 & 30 Varonica & 40 & 55 \\
15 & Dr. Harun Hudari & 80 & 100 & 31 Hesti Pratiwi & 10 & 50 \\
16 & Dr. Yudianita Kesuma & 80 & 100 & 32 Ridhotul Akbar & 65 & 65 \\
\hline
\end{tabular}

Sumber: Data diolah

Hasil survey pelatihan tersebut kemudian diuji perbedaan pengetahuan sebelum dan setelah pemberian materi dengan uji Wilcoxon. Uji Wilcoxon digunakan untuk menguji hipotesis terhadap dua variabel yang merupakan dua sampel berkaitan mempunyai distribusi yang sama atau berbeda. Uji Wilcoxon merupakan penyempurnaan Uji Tanda. Perbedaannya Uji Tanda hanya membahas perbedaan tanda, sedangkan Uji Wilcoxon selain membahas perbedaan tanda, juga 
membahas besaran perbedaan sebelum dan setelah perlakuan terhadap sampel.

Tim pengabdian memberikan pelatihan berupa penyuluhan yang diberikan dalam bentuk ceramah, diskusi, dan tes untuk melihat perubahan pengetahuan peserta tentang penguatan kapasitas dan kelembagaan ekonomi islam sebelum dan setelah pemberian materi kepada 32 orang peserta. Hasil yang diperoleh adalah sebagai berikut:

Tabel 2. Descriptive Statistics

\begin{tabular}{cccccc}
\hline & $\mathrm{N}$ & Mean & Std. Deviation & Minimum & Maximum \\
\hline Pretest & 32 & 62.0312 & 17.72821 & 10.00 & 90.00 \\
Posttest & 32 & 76.4062 & 15.35780 & 50.00 & 100.00 \\
\hline
\end{tabular}

Sumber: Data diolah

Secara statistik, besaran rata-rata posttest lebih tinggi dari pada pretest. Nilai rata-rata pretest sebesar 62.03 dan nilai rata-rata posttest sebesar 76.41. Hasil Uji Wilcoxon menunjukkan bahwa dari 32 peserta terdapat 26 peserta yang memperoleh nilai posttest lebih tinggi dari pada pretest dan 6 peserta memperoleh hasil yang sama. Hal ini menunjukkan bahwa sebagian besar peserta lebih memahami materi tentang penguatan kapasitas dan kelembagaan ekonomi islam setelah diberikan pelatihan.

Tabel 3. Wilcoxon Signed Ranks Test

\begin{tabular}{llrrr}
\hline & N & Mean Rank & Sum of Ranks \\
\hline Posttest - Pretest & Negative Ranks & $0^{\mathrm{a}}$ & .00 & .00 \\
& Positive Ranks & $26^{\mathrm{b}}$ & 13.50 & 351.00 \\
& Ties & $6^{\mathrm{c}}$ & & \\
& Total & 32 & & \\
\hline
\end{tabular}

a. Posttest < Pretest

b. Posttest $>$ Pretest

c. Posttest $=$ Pretest

Sumber: Data diolah

Rata-rata indeks pengetahuan peserta tentang penguatan kapasitas dan kelembagaan ekonomi islam jauh meningkat setelah diberikan pelatihan yaitu dari 62.03 poin menjadi 76.41 poin. Artinya, pelatihan penguatan kapasitas dan kelembagaan ekonomi islam yang dilakukan oleh tim pengabdian cenderung dapat meningkatkan pengetahuan peserta. Dugaan ini juga terbukti secara statistic dengan melihat nilai Asymp.Sig. 0.00 lebih besar dari $\alpha$ 0.05. Dimana Ho ditolak yang berarti indeks pengetahuan peserta meningkat setelah diberikan pelatihan tentang penguatan kapasitas dan kelembagaan ekonomi islam.

\subsection{Umpan Balik Khalayak Sasaran}

Seluruh peserta yaitu karyawan 212 mart, pengurus dan anggota koperasi warmat veteran utama dan lembaga ekonomi mahasiswa islam sangat antusias dan memberikan respon baik terhadap pelatihan penguatan kapasitas dan kelembagaan ekonomi islam yang diberikan. Sekitar 90 persen peserta telah memahami materi yang disampaikan dengan baik. Peserta berpendapat bahwa materi yang diberikan dan dipresentasikan sangat mudah dimengerti dan sesuai dengan harapan peserta.

Alokasi waktu yang ditentukan sangat baik dan diskusi yang dilakukan mencukupi untuk menambah atau memperkuat pemahaman peserta tentang materi penguatan kapasitas dan kelembagaan ekonomi islam. Sekitar 90 persen peserta juga menyetujui bahwa pemateri telah memberikan jawaban atas setiap pertanyaan peserta dengan baik. Secara keseluruhan diskusi/tanya-jawab telah sangat membantu meningkatkan pemahaman peserta. 
Tabel 4. Umpan Balik Khalayak Sasaran

\begin{tabular}{|c|c|c|c|c|c|c|}
\hline No & Pernyataan & $\begin{array}{l}\text { Sangat } \\
\text { Setuju }\end{array}$ & Setuju & Netral & $\begin{array}{l}\text { Tidak } \\
\text { Setuju }\end{array}$ & $\begin{array}{c}\text { Sangat } \\
\text { Tidak Setuju }\end{array}$ \\
\hline 1 & $\begin{array}{l}\text { Materi terorganisasi dengan baik dan mudah } \\
\text { dimengerti }\end{array}$ & $72.2 \%$ & $27.7 \%$ & & & \\
\hline 2 & $\begin{array}{l}\text { Materi sangat relevan dan telah sesuai dengan } \\
\text { yang saya harapkan }\end{array}$ & $50 \%$ & $50 \%$ & & & \\
\hline 3 & $\begin{array}{l}\text { Materi sudah mencukupi bagi saya untuk } \\
\text { mengetahui penguatan kapasitas dan } \\
\text { kelembagaan ekonomi islam }\end{array}$ & $50 \%$ & $44.4 \%$ & $5.6 \%$ & & \\
\hline 4 & $\begin{array}{l}\text { Dengan materi ini akan memudahkan saya untuk } \\
\text { melakukan penguatan kapasitas dan } \\
\text { kelembagaan ekonomi islam }\end{array}$ & $38.9 \%$ & $61.1 \%$ & & & \\
\hline 5 & $\begin{array}{l}\text { Pemateri sangat memahami materi yang } \\
\text { dipresentasikan }\end{array}$ & $61.1 \%$ & $38.9 \%$ & & & \\
\hline 6 & Alokasi waktu penyampaian materi mencukupi & $44.4 \%$ & $50 \%$ & $5.6 \%$ & & \\
\hline 7 & $\begin{array}{l}\text { Pemateri mempresentasikan isi materi dengan } \\
\text { baik; mudah dimengerti dan diimplementasikan }\end{array}$ & $61.1 \%$ & $38.9 \%$ & $5.6 \%$ & & \\
\hline 8 & $\begin{array}{l}\text { Alokasi waktu untuk diskusi mencukupi untuk } \\
\text { menambah / memperkuat pemahaman saya }\end{array}$ & $38.9 \%$ & $61.1 \%$ & $5.6 \%$ & & \\
\hline 9 & $\begin{array}{l}\text { Pemateri memberikan jawaban terhadap } \\
\text { pertanyaan peserta dengan baik }\end{array}$ & $44.4 \%$ & $55.6 \%$ & & & \\
\hline 10 & $\begin{array}{l}\text { Secara keseluruhan diskusi/tanya-jawab telah } \\
\text { sangat membantu meningkatkan pemahaman } \\
\text { peserta }\end{array}$ & $38.9 \%$ & $61.1 \%$ & & & \\
\hline
\end{tabular}

\section{Sumber: Data diolah}

Pelatihan penguatan kapasitas dan kelembagaan ekonomi islam memberikan pengetahuan dasar peserta terhadap penguatan ekonomi islam masyarakat. Penerima manfaat merupakan para pengurus dan panggota koperasi warmat veteran utama dan lembaga ekonomi mahasiswa islam serta karyawan 212 mart. Pentingnya penguatan ekonomi islam masyarakat untuk pemberdayaan ummat agar dapat mencapai kesejahteraan masyarakat.

\section{SIMPULAN}

Pemberdayaan ekonomi masyarakat telah menjadi program pemerintah seperti Program Keluarga Harapan (PKH), program bantuan UMKM, dan berbagai program lain untuk meningkatkan taraf hidup masyarakat dan kemandirian usaha kelompok kecil. Namun semua itu belum mencukupi, karena sebagian besar ummat masih terperangkap dengan sistem ekonomi kapitalisme yang mengeksploitasi nilai tambah ekonomi dari kegiatan ekonomi yang mengandung unsur ribawi, penipuan (tadlis), dan perjudian (maysir).

Kesadaran behijrah dari kegiatan ekonomi konvensional kapitalis ke kegiatan ekonomi islam telah menghadirkan lembaga ekonomi dan keungan mikro islam (LEKIS) seperti Baitul Mall wa Tamwil (BMT), Koperasi Syariah dengan usaha 212 Mart, Lembaga Ekonomi Mahasiswa Islam (LEMI), dan Amal Nyata Alumni HMI (ANA HMI).

Konsep penguatan kapasitas dan kelembagaan ekonomi islam perlu terus disosialisasikan kepada masyarakat dalam rangka pemberdayaan ekonomi ummat. Pengenalan penguatan kapasitas ekonomi merupakan usaha dari fakultas ekonomi Universitas Sriwijaya untuk meningkatkan taraf hidup dan mewujudkan kesejahteraan masyarakat.

Pelatihan penguatan kapasitas dan kelembagaan ekonomi islam perlu terus dilakukan secara berkelanjutan, mulai dari penyuluhan dan pengimplementasian untuk penguatan ekonomi masyarakat. Sebaiknya kegiatan pemberdayaan masyarakat termasuk pelatihan dalam penguatan ekonomi masyarakat harus terus dilaksanakan agar terwujudnya taraf hidup yang lebih baik. 


\section{UCAPAN TERIMA KASIH (ACKNOWLEDGMENTS)}

Kegiatan pengabdian ini didukung oleh anggaran DIPA dan rincian belanja satuan kerja Fakultas Ekonomi Universitas Sriwijaya. Kami berterima kasih kepada rekan-rekan kami dari Universitas Sriwijaya yang telah memberikan wawasan dan keahlian yang sangat membantu penelitian ini, atas komentar yang sangat menyempurnakan naskah.

\section{REFERENSI}

Antonio, M.S.. (2001). Bank Syariah: Dari Teori ke Praktik. Jakarta: Gema Insani.

Anwar, M. K. (2011). Penguatan Ekonomi Umat Melalui Lembaga Keagamaan. eL-Qist: Journal of Islamic Economic and Business (JIEB), 1(1), 89-102.

Departemen Koperasi. (2020). Data Perkembangan UMKM di Indonesia, diakses dari http://www.depkop.go.id, tanggal 17 Agustus 2020.

Departemen Koperasi. (2020). Profil Koperasi Syariah 212, diakses dari http://koperasisyariah212.co.id, tanggal 17 Agustus 2020.

Fahrudin, A. (2011). Pemberdayaan, Partisipasi dan Penguatan Kapasitas Masyarakat. Bandung: Humaniora.

Hamidi, I., Bashir, A., Atiyatna, D., Sukanto, S., \& Mukhlis, M. (2020). Pelatihan Manajemen Koperasi Syariah di Desa Kerinjing, Kabupaten Ogan Ilir, Sumatera Selatan. Sricommerce: Journal of Sriwijaya Community Services, 1(1), 9-16. doi:https://doi.org/10.29259/jscs.v1i1.5

Husni, I. S. (2020). Konsep Keadilan Ekonomi Islam Dalam Sistem Ekonomi: Sebuah Kajian Konsepsional. Islamic Economics Journal, 6(1), 57-74.

Iqbal, Z., \& Mirakhor, A. (2007). An Introduction to Islamic Finance. Jhon Wiley \& Sons, Asia Pre Ltd.

Karim, A. (2007). Ekonomi Mikro Islam, edisi ketiga. Jakarta: Rajawali Pers.

Mannan, M. A. (1995). Teori dan Praktek Ekonomi Islam. Yogyakarta: PT. Dana Bhakti Wakaf.

Milen, A. (2004). Pegangan Dasar Pengembangan Kapasitas. Yogyakarta: Pondok Pustaka Jogja.

Muhammad, (2002). Kebijakan Fiskal dan Moneter dalam Ekonomi Islam, Jakarta: Salemba Empat.

Pusat Pengkajian dan Pengembangan Ekonomi Islam (P3EI) UII. (2019). Ekonomi Islam. Cetakan ke8, Jakarta: Raja Grafindo Persada.

Singgih, M. N. (2007). Strategi Penguatan Usaha Mikro Kecil Menengah (UMKM) Sebagai Refleksi Pembelajaran Krisis Ekonomi Indonesia. Jurnal Ekonomi MODERNISASI, 3(3), 218-227.

Soediro, A., Kusumawardani, M., Farhan, M., Adhitama, F., Yusrianti, H., Bashir, A., \& Hamidi, I. (2021). Literasi Ekonomi Islam menuju Pusat Industri Halal Dunia. Sricommerce: Journal of Sriwijaya Community Services, 2(1), 39-46. doi:https://doi.org/10.29259/jscs.v2i1.34.

Sudarsono, H. (2007). Bank dan Lembaga Keuangan Islam. Ekonisia-UII, Yogyakarta.

Yusuf, M., \& Tawai, D. A. (2019). The Application Capacity Building Model of Government Apparatus to Improve Public Services Quality in Southeast Sulawesi. Academic Research International, 10(4), 120-127. 